\title{
Study of the Influence of the Banking Sector Development on the Inflows of Foreign Investment in Nigeria and Ghana
}

\author{
Chigbu, Uzoamaka S. (Ph.D) ${ }^{1, a}$, Ubah, Chijindu Promise ${ }^{2, b}$, \\ Chigbu, Ezeji E. (Ph.D) $)^{3, c}$ \\ ${ }^{1}$ Department of Banking and Finance, Imo State University, Owerri, Nigeria \\ ${ }^{2}$ Department of Financial Management Technology, Federal University of Technology, \\ Owerri, Nigeria \\ ${ }^{3}$ Department of Financial Management Technology, Federal University of Technology, \\ Owerri, Nigeria \\ asussychigbu@yahoo.com bubahchijindup@yahoo.comc sussychigbu@yahoo.com
}

Keywords: Banking Sector Development, Foreign Investment, Domestic Credit to Private sector, Bank Lending Rate and Return on Investment.

\begin{abstract}
The level of bank development has a determinant effect on the growth potentials of a developing economy. In response, this study examined the impact of banking sector development on foreign investment inflows in the West African countries of Nigeria and Ghana. The study relied on secondary data for analysis and made use of multiple regression technique. However, to ensure the authenticity of our result, Augmented Dickey-Fuller unit root test and Johansen Cointegration techniques were respectively employed to test for the presence unit root and long-run equilibrium relationship in the exogenous variables. Additionally, causal relationships were tested with Granger Causality. It was revealed that banking sector development has a significant influence on foreign investment inflows in the two West African countries. Specifically, domestic credit to private sector and bank deposit rate has significant influence on foreign investment inflows in both countries. Whereas domestic credit to private sector is directly related to the dependent variable in Ghana, it is related inversely in Nigeria. It was also discovered that bank lending rate is significantly and positively related to foreign investment in Ghana. Intermediation efficiency and profitability of banks should be improved by enhancing the capital structure and adopting the appropriate lending rate especially in Nigeria as measures to attract more inflows of foreign investment in both countries.
\end{abstract}

\section{Introduction}

Investment is the most strategic factor in the process of economic development and as such the need for foreign investment inflow into developing countries is crucial. Foreign investment represents a veritable source of foreign exchange and technological transfer, especially to developing economies. It can be analyzed in terms of inflows of new equity capital, re-invested earning, trade and supplier's credit, net inflow of borrowing and other obligations from the parent company or its affiliates [1]. It can impact the host economy through a variety of channels. Principally, it helps by adding to the resources available for investment and capital formation. The transfer of technology, skills, innovative capacity, organizational and managerial practices between countries are also enhanced through the activities of foreign direct investors [2].

Paucity of capital has stalled the growth potential of Africa considering the fact that the savings-investment deficit is wide enough that domestic capital can hardly close such, hence the need for foreign capital. Africa has not been able to attract adequate foreign investment that will meet the economic growth requirement due to poor economic background [3]. In addition to this, African countries are vulnerable to harsh weather situations, poor infrastructural development and political instability [4]. Also, there are other financial indicators which have discouraged the inflows of foreign investment in African countries. They include high and unstable lending rate, high collateral requirement for banks credit, exchange rate volatility, aggregate price instability, 
poor investment policy, harsh economic policies, underdeveloped financial markets and undiversified economy among others.

Regardless of the poor economic outing, African economies especially Nigeria has witnessed huge inflow of foreign investment in recent times. The world economic forum in 2014 posits that Africa has the potentials of becoming the world centre of foreign investment. Between 2000-2004, 2005-2009 and 2010-2013, Nigeria alone attracted \$8billion, \$31billion and \$36billion respectively. According to [5], Africa remains a major partner in doing business because it is believed that her workforce is young and energetic. In recent times, Africa has equally scored some political and economic points that will boost the inflows of foreign investment into the continent. The constant growth in the economy, growth in the financial market, tax reforms (tax haven on foreign investments) and politically stability especially as witnessed in Nigeria and Ghana recently, among others speak volume in this direction.

The present study therefore investigates the role and impact of banking sector development on foreign investment inflows in two neighboring West African countries; Ghana and Nigeria which have similar economic growth prospects, political structure and climatic conditions as well as natural endowment.

\section{Literature Review}

\subsection{The Concept of Foreign Investment}

Investment, according to [6], is defined as commitment of fund to a given economic activities in anticipation for future benefits or future consumption, or as the process of postponing immediate consumption in anticipation for future benefits. Foreign investment is defined as the trend toward globalization whereby large multinational firms often have investments in a great variety of countries. It is the flow of capital from one nation to another in exchange for significant ownership stakes in domestic companies or other domestic assets [7]. As increased globalization in business has occurred, it become very common for big firms to branch out and invest money in companies located in other countries. These companies may be opening up new production plants and attracted to cheaper labour, availability of raw materials, favorable tax policies and developed financial market in another country. Absolutely, foreign investment in a country is a good sign that often leads to growth of jobs, income among other economic benefits.

Foreign investment is divided into direct and portfolio investment. Foreign private investment (FPI) is an investment made to acquire a lasting management interest (normally $10 \%$ of voting stock) in a business enterprise operating in a country other than that of the investor defined according to residency [8]. This involves physical investment and purchase of buildings, factories, machines and other equipment outside their home country. Portfolio investment is the stake a company has in another company and country. In the study of [9] sees foreign investment as a component of foreign direct and foreign portfolio assets. He further explained that portfolio investment involves the purchase of a stake in an enterprise by a foreign equity investor, or purchase of financial securities that normally have a short time horizon.

\subsection{Theories of Foreign Investment}

\subsubsection{Theories of Foreign Investment Based On Perfect Competition}

The early works of FDI theory can be traced in the work by [10] who established his model based on the assumptions of perfectly competitive market. His theory was further elaborated by [11]. Assuming a two-country model and prices of capital being equal to its marginal productivity, MacDougall and Kemp both stated that when there was free movement of capital from an investing country to a host country, the marginal productivity of capital tended to be equalized between the two countries. They found that after investment, the output of the investing country fell without any decrease in the national income of the country. This is because in the long-term, the investing country gets higher income from its investment abroad. 


\subsubsection{The Theory of Exchange Rates on Imperfect Capital Markets}

[12] and [13] analyzed the influence of uncertainty as a factor of foreign investment. Cushman showed that real exchange rate increase stimulated foreign investment made by US dollar, while a foreign currency appreciation has reduced American foreign investment. Cushman concludes that the dollar appreciation has led to a reduction in United States foreign investment by $25 \%$. However, currency risk rate theory cannot explain simultaneous foreign direct investment between countries with different currencies. The sustainers argue that such investments are made in different times, but there are enough cases that contradict these claims.

\subsubsection{The Internalization Theory}

This theory explained the growth of transnational companies and their motivations for achieving foreign direct investment. The theory was developed by [14], and then by [15], and [16]. Initially, the theory was launched by [17] in a national context and [18] in an international context. In his Doctoral Dissertation, Hymer identified two major determinants of foreign direct investment. One was the removal of competition; the other was the advantages which some firms possess in a particular activity [18]. Buckley and Casson, who founded the theory demonstrates that transnational companies are organizing their internal activities so as to develop specific advantages, which then to be exploited. [15] developed the idea of internalization by developing models between the two types of integration: vertical and horizontal. Hymer is the author of the concept of firm-specific advantages and demonstrates that foreign direct investment take place only if the benefits of exploiting firm-specific advantages outweigh the relative costs of the operations abroad. According to [18], the multinational enterprise appears in existence due to the market imperfections that led to a divergence from perfect competition in the final product market. Hymer has discussed the problem of information costs for foreign firms in respected to local firms, different treatment of governments, currency risk [19]. Hymer recognized that FDI is a firm-level strategy decision rather than a capital-market financial decision.

\subsubsection{Location-Specific Theory}

[20] stressed on the location-specific advantages. He argued that since real wage cost varies among countries, firms with low cost technology move to low wage countries. Again, in some countries, trade barriers are created to restrict import. Multi-National Corporations (MNCs) invest in such countries in order to start manufacturing there, and evade trade barriers. Sometimes it is the availability of cheap and abundant raw material that encourages the MNCs to invest in the country with abundant raw material.

\subsubsection{Eclectic Paradigm}

Dunning's eclectic paradigm is a combination of the major imperfect market-based theories of capital inflows, i.e. industrial organization theory, internalization theory and location theory. It postulates that, at any given time, the stock of foreign assets owned by a multinational firm is determined by a combination of firm specific or ownership advantage, $(\mathrm{O})$ the extent of location bound endowments, (L) and the extent to which these advantages are marketed within the various units of the firm (I). Dunning is conscious that configuration of the O-L-I advantages varies from one country to the other and from one activity to the other. Foreign investment will be greater where the configuration is more pronounced. Again, he introduces a "dynamised add-on" variable to his theory. This is nothing but a variable of strategic change, which may be either autonomous or a strategy induced change. International production during a particular period would be the sum of the strategic responses of the firm to the past configuration of O-L-I and to changes in such configuration as a sequel to exogenous and endogenous changes in environment. The example of autonomous change in strategy may be that a firm makes foreign investment more in innovatory activities because of greater O-advantage, or it invests more in a particular country because of L-advantage or it adopts a different marketing strategy depending upon the greater amount of I-advantage. Similarly, the strategy induced change may be evident from the fact that a market 
seeing investment has a different O-L-I configuration from that of a resource based investment. And ultimately, it is the varying configuration that shapes the direction and the pattern of FDI $[21,22]$.

\subsubsection{Portfolio Theory}

[23] provided a normative approach to investors to make decisions to invest their wealth in assets under risk, also provides the portfolio selection that serves as a guide for those who wishes to research into the world of portfolio optimization. The fundamental concept behind the theory is that the assets in an investment portfolio should not be selected individually, each on its own merits. Rather, it is important to consider how each asset changes in price relative to how every other asset in the portfolio changes in price. Investing is a tradeoff between risk and expected return. In general, assets with higher expected returns are riskier. For a given amount of risk, Markowitz described how to select a portfolio with the highest possible expected return and vice versa.

\subsection{Empirical Review}

\subsubsection{Banking Sector Development}

The direction of causal relationship between economic growth and the banking sector is one area of contention amongst economists. [24] for example was a strong advocate of the role of the banking sector in stimulating economic growth and stated that "The banker stands between those who wish to form new combinations and the possessors of productive means. He is essentially a phenomenon of development, though only when no central authority directs the social process. He makes possible the carrying out of new combinations, authorizes people, in the name of the society as it were, to form them. He is the ephor of the exchange economy." [25] however argue that banking activity and profitability are a function of economic growth.

[3] focused on the impact of economic indicators of Banking Sector Development Model on foreign investment inflows in Nigeria and South Africa. Various data on banking sector; economic indicators of the classified model were sourced from state statistical bulletins as well as World Bank for the year of 1980-2013. The analysis employed several econometric tools: Unit root, Cointegration, VAR estimates of relative and global statistics to measure the impact and significance of economic indicators attracting/repelling foreign investments. Akaike information criteria for best model selection results showed that economic indicators of Banking Sector Development Model in Nigeria attracted more foreign investment than it did in South Africa. The study concluded that the optimal economic indicators attracting foreign investment are domestic credit and inflation rate. [2] examined the impact of interest rate on FDI flow in Sierra Leone, as the government of Sierra Leone has made tremendous effort after the civil war ended in 2001 to attract more foreign investment through the implementation of favorable foreign investment policies. Using econometrics techniques to run multiple regression time series data for the period of1985 to 2012 in which diagnostic test was carried out in order to make the model fit and free from all spuriousness and make result valuable. The main findings were; trade openness (TO) and exchange rates (ER) are the key determinants of FDI flow having positive significant signs in Sierra Leone. Others variables, such as inflation, gross domestic products (GDP) and interest rate (IR), were found to be insignificant factors causing the variability of FDI flows. Finally, they accept the null hypothesis that; high interest rate has no effect on FDI flow in Sierra Leone. [25] explored the relationship between foreign direct investment and financial sector growth, providing empirical evidence from Nigeria. Annual time-series data were gathered on foreign direct investment, market capitalization, Gross Domestic Product, External Debt, Inflation rate, Exchange Rate and Degree of openness from 1981 -2010. The empirical model was analyzed using the econometric techniques of ordinary least square method, unit root test, co-integration test, Error correction Mechanism, and Granger causality test. The findings suggest that the inflow of FDI has a positive impact on the Financial Sector in the short run but fail to translate to real long financial sector growth that could promote speedy economic growth due to the fact that the bulk of foreign direct investment has been channeled to other sectors of the economy namely the Oil and Gas Sector 
According to [26], banking sector openness had a direct and indirect effect on economic growth through a combination of improvement in access to financial services, and the efficiency of financial intermediaries as both of these cause a lowering of costs of financing which in turn stimulates capital accumulation and economic growth. [26] demonstrated that the role of foreign banks was both statistically and economically significant in increasing growth and improving the operations of local banks. However, [27] found that soft budget constraints and repeated bank bailouts by governments were a function of poor quality of loan portfolios, the absence of collateral, low bank capitalization, and political pressure to refinance unprofitable firms in transitional economies.

[28] used the ratio of banks' claims on the private sector to GDP, annual consumer price index, and the interest rate margin to analyze the relationship between finance and economic growth. The models specified by [29] theoretical models were more expansive and included money supply, minimum rediscount rates, private sector credit, ratio of banking sector credit to government, ratio of stock market capitalization to credit to the private sector, and exchange rates. Many of these variables are however often incomplete, subjective, and difficult to systematically compare. [29] used a fixed-effects panel model and data from 25 transition countries for the period 1993-2000; however, he acknowledged that deposit and lending rates are unavailable for identical periods for each country. In his word, 'as we do not have financial sector data on many CIS countries in the first half of 1990s, we lose many observations and the results for the reform index are different than in earlier papers'.

[30] examined bank fund reallocation and regional economic growth based on 1991-2005 provincial-level data of four state-owned commercial banks of China. They found no correlation at the regional level between fund reallocation and bank loans on the one hand and economic growth on the other. [31] examined the relationship between banks and economic growth in Nigeria. The study adopts linear regression function and specifies that the level of real Gross Domestic Product, which is a measure of economic activity, is a function of banks credit to the economy which is a measure of the contribution of banks. The results of the models estimated show that banks have positive impacts on economic growth in Nigeria. [32] examined the role of banks deposit money in the growth of Nigerian economy. The study was based on time series; data for the study were sourced from the Federal Bureau of Statistics, CBN statistical bulletin which covered 1974-2010. The co-integration and error correction model and structural analysis were used, both ADF and PP was adopted in testing for the unit root. At the end of our analysis, he discovered that there exist a long-run relationship between the dependent and the explanatory variables. The results conform to the economic a priori expectation. Thus, policies that tend to increase the gross domestic product through the financial sector such as increase in banks deposit liability, low interest rate, high liquidity ratio were recommended for better economy.

\section{Methodology}

The present study is designed to determine if the banking sector development has influenced the inflows of foreign investment in west African countries, specifically Nigeria and Ghana from 1980-2014. This choice of the period was informed on the various reforms, developments and deregulation of the banking sector as well as improvement in the inflows of foreign investment in the two countries. Data were majorly obtained from Central Bank of Nigerian Statistical Bulletin, World Bank Economic Indicators, African Development Bank and International Monetary Fund Economic Outlook. The variables used in the study include foreign investment (FI) is the sum of foreign direct investment and foreign portfolio investment, return on investment (ROI), domestic credit to private sector (CPS), bank deposit rate (BDR) and lending rate (BLR).

\subsection{Empirical Model Specification}

The functional representation of the relationship between banking sector development and foreign investment is stated as follows:

$$
F I_{t}=f\left(B S D_{t}, u_{t}\right) \text {. }
$$




$$
B S D=f(R O I, C P S, B D R \text { and } B L R) .
$$

The model is further represented in parametric form in equation 3.3 below;

$$
F I_{t}=\alpha_{0}+\alpha_{1} R O I_{t}+\alpha_{2} C P S_{t}+\alpha_{3} B D R_{t}+\alpha_{4} B L R_{t}+\mu_{t} .
$$

To remove the problem of time-invariant characteristics inherent in time series data, we take the natural logarithm of each of the variables, thus:

$$
\ln F I_{t}=\alpha_{0}+\alpha_{1} \ln R O I_{t}+\alpha_{2} \ln C P S_{t}+\alpha_{3} \ln B D R_{t}+\alpha_{4} \ln B L R_{t}+\mu_{t}
$$

where FI is the sum of foreign direct investment and foreign portfolio investment representing foreign investment, ROI is average return on investment of banks, CPS is domestic credit to private sector, BDR is average bank deposit rate, BLR is average lending rate, $\alpha_{0}$ is constant term, $\alpha_{1}-\alpha_{4}$ are coefficient of parameters, $\ln$ is natural logarithm, $\mu$ is random residual term, $t$ is the time period under investigation.

A priori sign of parameters: $\alpha_{1}>1, \alpha_{2}>1, \alpha_{3}>1, \alpha_{4}<1$.

\section{Data Analysis and Results}

\subsection{Stationary Test for Times Series Data}

Time series data are prone to problems of spuriousness if the data are not stationary. It has been asserted that if a times series data is nonstationary, all the usual regression results will suffer from spurious regression [33]. Hence, the Augmented Dickey-Fuller unit root was used to test the

\begin{tabular}{|c|c|c|c|c|c|}
\hline Variables & $\begin{array}{c}\text { ADF } \\
\text { Statistics }\end{array}$ & $\begin{array}{l}\text { Critical } \\
\text { Values }\end{array}$ & $\begin{array}{c}\text { Order of } \\
\text { Integration }\end{array}$ & Conclusion & Stage \\
\hline \multicolumn{6}{|c|}{ NIGERIA } \\
\hline FI & -4.7824 & $-3.6537 *$ & $\mathrm{I}(0)$ & Stationary & Level \\
\hline ROI & -4.3974 & $-3.9591^{*}$ & $\mathrm{I}(1)$ & Stationary & $1^{\text {st }}$ diff \\
\hline CPS & -5.2151 & $-3.6463^{*}$ & $\mathrm{I}(1)$ & Stationary & $1^{\text {st }}$ diff \\
\hline BDR & -4.4230 & $-3.6394 *$ & $\mathrm{I}(0)$ & Stationary & Level \\
\hline BLR & -5.7090 & $-3.6537^{*}$ & $\mathrm{I}(1)$ & Stationary & $1^{\text {st }}$ diff \\
\hline \multicolumn{6}{|c|}{ GHANA } \\
\hline FI & -3.8055 & $-3.6463^{*}$ & $\mathrm{I}(1)$ & Stationary & $1^{\text {st }}$ diff \\
\hline ROI & -3.5284 & $-3.0989 * *$ & $\mathrm{I}(1)$ & Stationary & $1^{\text {st }}$ diff \\
\hline CPS & -7.2178 & $-3.6463 *$ & $\mathrm{I}(1)$ & Stationary & $1^{\text {st }}$ diff \\
\hline BDR & -8.2273 & $-3.6463^{*}$ & $\mathrm{I}(1)$ & Stationary & $1^{\text {st }}$ diff \\
\hline BLR & -4.7626 & $-3.6463 *$ & $\mathrm{I}(1)$ & Stationary & $1^{\text {st }}$ diff \\
\hline
\end{tabular}
stationarity of the time series data. The summary of the results are shown in table 4.1 below.

Table 4.1: Results of Augmented Dickey-Fuller Unit Root Rest

Note:*@1\% critical value, **@5\% critical value; Source: Eview Statistical Package 7.1

The results of the unit root test summarized in table 4.1 above revealed that the variables of return on investment (ROI), domestic credit to private sector (CPS), and bank lending rate (BDR) are integrated of degree 1 in both countries. It was equally discovered that where as foreign investment (FI) and bank deposit rate (BDR) are stationary at first order I(1) in Ghana, they are stationary at zero order in Nigeria.

\subsection{Long-run Cointegration Estimation}

With the results of the above unit-root tests suggesting that majority of the variables are integrated at first order I(I), we move a step further to employ the [34] and [35] procedures to test 
for cointegration among the variables. The Johansen methodology is a generalization of the DickeyFuller test. Two likelihood ratio tests (trace and maximum eigenvalue) were used to test the hypotheses regarding the number of cointegrating vectors. Table 4.2 and 4.3 below are the results of cointegration test (Trace and Maximum Eigen Statistic) for Nigeria and Ghana.

Table 4.2: Johansen Cointegration Test (Nigeria)

Unrestricted Cointegration Rank Test (Trace)

\begin{tabular}{ccccc}
\hline \hline $\begin{array}{c}\text { Hypothesized } \\
\text { No. of CE(s) }\end{array}$ & Eigenvalue & $\begin{array}{c}\text { Trace } \\
\text { Statistic }\end{array}$ & $\begin{array}{c}0.05 \\
\text { Critical Value }\end{array}$ & Prob. ${ }^{* *}$ \\
\hline \hline None & 0.484317 & 48.49253 & 69.81889 & 0.7017 \\
At most 1 & 0.415582 & 28.62466 & 47.85613 & 0.7859 \\
At most 2 & 0.230082 & 12.51052 & 29.79707 & 0.9126 \\
At most 3 & 0.143398 & 4.666387 & 15.49471 & 0.8432 \\
At most 4 & 0.000764 & 0.022915 & 3.841466 & 0.8796 \\
\hline \hline
\end{tabular}

Trace test indicates no cointegration at the 0.05 level

* denotes rejection of the hypothesis at the 0.05 level

**MacKinnon-Haug-Michelis (1999) p-values

Unrestricted Cointegration Rank Test (Maximum Eigenvalue)

\begin{tabular}{ccccc}
\hline \hline $\begin{array}{c}\text { Hypothesized } \\
\text { No. of CE(s) }\end{array}$ & Eigenvalue & $\begin{array}{c}\text { Max-Eigen } \\
\text { Statistic }\end{array}$ & $\begin{array}{c}0.05 \\
\text { Critical Value }\end{array}$ & Prob. $^{* *}$ \\
\hline \hline None & 0.484317 & 19.86786 & 33.87687 & 0.7657 \\
At most 1 & 0.415582 & 16.11415 & 27.58434 & 0.6561 \\
At most 2 & 0.230082 & 7.844128 & 21.13162 & 0.9130 \\
At most 3 & 0.143398 & 4.643472 & 14.26460 & 0.7860 \\
At most 4 & 0.000764 & 0.022915 & 3.841466 & 0.8796 \\
\hline \hline
\end{tabular}

Max-eigenvalue test indicates no cointegration at the 0.05 level

* denotes rejection of the hypothesis at the 0.05 level

**MacKinnon-Haug-Michelis (1999) p-values

Table 4.2 above presents result of trace and maximum eigenvalue test for unrestricted co-integration rank test. Results from the tests indicate that no cointegrating equation is found in trace and maximum eigenvalue tests at $5 \%$ critical value. Therefore, the null hypotheses of no co-integrating vectors $(r=0 ; r \leq 1)$ against the specific alternatives are clearly accepted since all the vectors of the trace and maximum (test) statistics are less than $5 \%$ critical value.

Table 4.3 presents result of trace and maximum eigenvalue test for unrestricted co-integration rank test. Results from the tests indicate that 1 cointegrating equation is found in trace and maximum eigenvalue test at $5 \%$ critical value. Therefore, the null hypotheses of no co-integrating vectors $(\mathrm{r}=$ $0 ; \mathrm{r} \leq 1)$ against the specific alternatives are clearly rejected since trace and maximum statistic of 83.93294 and 69.81889 are greater than their respective $5 \%$ critical values of 36.16704 and 33.87687 . 
Table 4.3: Johansen Cointegration Test (Ghana)

Unrestricted Cointegration Rank Test (Trace)

\begin{tabular}{ccccc}
\hline \hline $\begin{array}{c}\text { Hypothesized } \\
\text { No. of CE(s) }\end{array}$ & Eigenvalue & $\begin{array}{c}\text { Trace } \\
\text { Statistic }\end{array}$ & $\begin{array}{c}0.05 \\
\text { Critical Value }\end{array}$ & Prob. $^{* *}$ \\
\hline \hline None * & 0.665785 & 83.93294 & 69.81889 & 0.0025 \\
At most 1 & 0.513472 & 47.76590 & 47.85613 & 0.0510 \\
At most 2 & 0.402203 & 23.99068 & 29.79707 & 0.2008 \\
At most 3 & 0.140652 & 7.012045 & 15.49471 & 0.5762 \\
At most 4 & 0.059087 & 2.009850 & 3.841466 & 0.1563 \\
\hline \hline
\end{tabular}

Trace test indicates 1 cointegrating eqn(s) at the 0.05 level

* denotes rejection of the hypothesis at the 0.05 level

**MacKinnon-Haug-Michelis (1999) p-values

Unrestricted Cointegration Rank Test (Maximum Eigenvalue)

\begin{tabular}{ccccc}
\hline \hline $\begin{array}{c}\text { Hypothesized } \\
\text { No. of CE(s) }\end{array}$ & Eigenvalue & $\begin{array}{c}\text { Max-Eigen } \\
\text { Statistic }\end{array}$ & $\begin{array}{c}0.05 \\
\text { Critical Value }\end{array}$ & Prob. ${ }^{* *}$ \\
\hline \hline None * & 0.665785 & 36.16704 & 33.87687 & 0.0262 \\
At most 1 & 0.513472 & 23.77522 & 27.58434 & 0.1428 \\
At most 2 & 0.402203 & 16.97863 & 21.13162 & 0.1730 \\
At most 3 & 0.140652 & 5.002195 & 14.26460 & 0.7416 \\
At most 4 & 0.059087 & 2.009850 & 3.841466 & 0.1563 \\
\hline \hline
\end{tabular}

Max-eigenvalue test indicates 1 cointegrating eqn(s) at the 0.05 level

* denotes rejection of the hypothesis at the 0.05 level

**MacKinnon-Haug-Michelis (1999) p-values

Table 4.4: Pairwise Granger Causality Test (Nigeria)

Lags: 2

\begin{tabular}{lccc}
\hline \hline Null Hypothesis: & Obs & F-Statistic & Prob. \\
\hline \hline ROI does not Granger Cause FI & 33 & 1.40136 & 0.2907 \\
FI does not Granger Cause ROI & & 0.79048 & 0.4800 \\
\hline \hline BDR does not Granger Cause FI & 33 & 3.86263 & 0.0351 \\
FI does not Granger Cause BDR & & 0.54747 & 0.5845 \\
\hline \hline CPS does not Granger Cause FI & 33 & 4.14908 & 0.0289 \\
FI does not Granger Cause CPS & & 0.23002 & 0.7960 \\
\hline \hline BLR does not Granger Cause FI & 33 & 0.37795 & 0.6894 \\
FI does not Granger Cause BLR & & 0.19601 & 0.8231 \\
\hline \hline
\end{tabular}

The result of Granger causality test showed a uni-directional causal relationship is existent from bank deposit rate and domestic credit to private sector to foreign investment respectively, given that their probability values of 0.0351 and 0.0289 are less than the 0.05 critical value decision benchmark. This result posits that previous variations in bank deposit rate and domestic credit to private sector have predicting effect on foreign investment inflows in Nigeria. 
Table 4.5: Pairwise Granger Causality Test (Ghana)

Lags: 2

\begin{tabular}{lccc}
\hline \hline Null Hypothesis: & Obs & F-Statistic & Prob. \\
\hline \hline BDR does not Granger Cause FI & 33 & 3.63577 & 0.0425 \\
FI does not Granger Cause BDR & & 6.33563 & 0.0054 \\
\hline \hline BLR does not Granger Cause FI & \multirow{2}{*}{33} & 3.85640 & 0.0359 \\
FI does not Granger Cause BLR & & 4.04502 & 0.0286 \\
\hline \hline CPS does not Granger Cause FI & \multirow{2}{*}{33} & 9.21030 & 0.0012 \\
FI does not Granger Cause CPS & & 0.67807 & 0.5157 \\
\hline \hline ROI does not Granger Cause FI & \multirow{2}{*}{15} & 2.88502 & 0.0762 \\
FI does not Granger Cause ROI & & 0.65987 & 0.5380 \\
\hline \hline
\end{tabular}

With reference to table 4.5 above, bi-directional causal relationship exist between foreign investment inflow and bank deposit rate, and between bank lending rate and foreign investment respectively. It is also evident in the result that domestic credit to private sector granger cause foreign investment inflow. This result is obvious since their respective probability values are less than the 0.05 critical probability value. This implies that historical changes in bank lending, deposit rate and domestic credit to private sector have a predictive effect on foreign investment inflows in Ghana.

Table 4.6: Presentation of Results of Least Square Regression (Nigeria)

\begin{tabular}{|l|l|l|l|l|}
\hline Regressor & Coefficient & $\begin{array}{l}\text { Standard } \\
\text { Error }\end{array}$ & t-Statistic & Probability Value \\
\hline Constant & 354435.9 & 512667.6 & 0.691356 & 0.4948 \\
\hline ROI & 17170.14 & 10231.77 & 1.678120 & 0.1041 \\
\hline CPS & -140581.4 & 28452.58 & -4.940902 & 0.0000 \\
\hline BDR & 343977.1 & 44550.97 & 7.720978 & 0.0000 \\
\hline BLR & -7242.163 & 19092.02 & -0.379329 & 0.7072 \\
\hline R-square 0.6767 & \multicolumn{2}{|l|}{ Akaike info criterion } & 29.22903 \\
\hline Adj R-Square & 0.6321 & \multicolumn{2}{l|}{ Schwarz criterion } & 29.4535 \\
\hline Durbin-Watson & 2.0001 & F-Statistic &
\end{tabular}

The linear econometric model is presented in equation 4.1 below;

$$
F I=17170.14 R O I-140581 C P S+343977.1 B D R-7242.16 B L R+354435.9
$$

The regression results in Table 4.6 above shows that the intercept of the model is 354435.9. This implies that when the measures of Nigerian banking sector development variables as used in this study are fixed or held constant, foreign investment inflow into the country increase by 354435.9 units. The coefficients of return on investment and bank deposit rate of 17170.14 and 343977.1 indicate that both variables are directly related to foreign investment inflows. It therefore implies that a unit increase in return on investment and bank deposit rate will respectively increase foreign investment by 17170.14 and 343977.1 units. In contrast, the negative coefficients of domestic credit to private sector and bank lending rate revealed that the two variables are inversely related to foreign investment inflows. Quantitatively, a unit increase in bank credit to private sector and bank lending rate will have declining effect of 140581.4 and 7242.163 units on foreign investment inflows, respectively.

The value of R-square adjusted of 0.6321 is an indication that $63.21 \%$ of changes in foreign investment inflow in Nigeria are accounted for by the joint variation of the banking sector 
development variables used in this study while the remaining $36.8 \%$ is accounted for by factors not specified in the model. In addition to this, the F-statistic of 15.173 with probability value of 0.000001 is a strong indication that the model is statistically significant and the banking sector development is determinantial to foreign investment inflows in Nigeria.

Further analysis of the statistic of each of the explanatory variables revealed that banking sector credit to private sector and bank deposit rate are statistically significant in predicting foreign investment inflows in Nigeria. However, the return on investment and bank lending rate respectively do not have significant effect on foreign investment inflows in Nigeria.

Table 4.7: Presentation of Results of Least Square Regression (Ghana)

\begin{tabular}{|c|c|c|c|c|}
\hline Regressor & Coefficient & $\begin{array}{l}\text { Standard } \\
\text { Error }\end{array}$ & t-Statistic & Probability Value \\
\hline Constant & 19.9716 & 5.4552 & 3.6610 & 0.0033 \\
\hline ROI & -0.2018 & 0.0981 & -2.0579 & 0.0620 \\
\hline CPS & 0.7931 & 0.2253 & 3.5194 & 0.0042 \\
\hline BDR & 0.3293 & 0.0856 & 3.8445 & 0.0023 \\
\hline$\overline{B L R}$ & 0.5008 & 0.1458 & 3.4349 & \multirow{2}{*}{$\frac{0.0049}{.9509}$} \\
\hline R-square & 0.8081 & \multicolumn{2}{|c|}{ Akaike info criterion } & \\
\hline Adj R-square & 0.7442 & \multicolumn{2}{|c|}{ Schwarz criterion } & 4.1960 \\
\hline Durbin-Watson & 1.6399 & F-Statistic & \multicolumn{2}{|c|}{$12.6356(0.000292)$} \\
\hline
\end{tabular}

The linear econometric model is presented in equation 4.2 below;

$$
F I=-0.2018 R O I+0.7931 C P S+0.3293 B D R+0.5008 B L R+19.972
$$

The regression results in Table 4.7 above shows that the intercept of the model is 19.9716. This implies that when the measures of Ghanaian banking sector development variables as used in this study are fixed or held constant, foreign investment inflow into the country will increase by 19.9716 units. The coefficients of domestic credit to private sector, bank deposit rate and bank lending rate of $0.7931,0.3293$ and 0.5008 signify that the three variables are positively related to foreign investment inflow in Ghana. This precisely means that a unit increase in domestic credit to private sector, bank deposit rate and bank lending rate will increase foreign investment by $0.7931,0.3293$ and 0.5008 respectively. Conversely, the negative coefficients of return on investment signify that return on investment have inverse effect on foreign investment in Ghana. In principle, a unit increase in return on investment will decrease foreign investment by 0.2018 .

The value of R-square adjusted of 0.7442 is an indication that the model is strongly fitted. This means that $74.4 \%$ of changes in foreign investment inflow in Ghana are accounted for by the joint variation of the banking sector development variables used in this study while the remaining $25.6 \%$ is accounted for by unspecified factors in the model. More so, the F-statistic of 12.6356 with probability value 0.000292 is a strong indication that the model is statistically significant and adequately signifies that banking sector development has a strong influence on the inflows of foreign investment in Ghana.

Further analysis of the statistic of each of the explanatory variables revealed that banking sector credit to private sector, bank deposit rate and bank lending rate confirmed that these variables are statistically significant in predicting foreign investment inflows in Ghana. Conversely, return on investment proof that the parameter does not have a significant effect on foreign investment inflows in Ghana. 
Table 4.8: Summary of Result Statistics

\begin{tabular}{|l|l|l|l|}
\hline Variables & Statistics & Nigeria & Ghana \\
\hline & t-statistic & 1.6781 & -2.0579 \\
ROI & p-values & 0.1041 & 0.0620 \\
\hline & t-statistic & -4.9409 & 3.5194 \\
CPS & p-values & 0.0000 & 0.0042 \\
\hline & t-statistic & 7.7210 & 3.8445 \\
BDR & p-values & 0.0000 & 0.0023 \\
\hline & t-statistic & -0.3793 & 3.4349 \\
BLR & p-values & 0.7072 & 0.0049 \\
\hline Constant & t-statistic & 0.6914 & 3.6610 \\
& p-values & 0.4948 & 0.0033 \\
\hline & R-square Adj & 0.6321 & 0.7442 \\
\hline & F-statistics & 15.1735 & 12.6356 \\
& F-stat (prob) & 0.000001 & 0.000292 \\
\hline
\end{tabular}

Source: Researchers' computation

\subsection{Implication of the Results}

In general terms, the results of this study gave rise to several policy issues. To be specific, the return on investment has direct but insignificant impact on foreign investment in Nigeria. This finding is in line with the contemporary Nigeria, as many banks were found technically insolvent in the recent past, while some were bailed out by the central government of the country for them to continue to be in business, others were acquired by the Asset Management Company of Nigeria (AMCON) as toxic assets. In Ghana, return on investment is not only insignificant but inversely related to foreign investment inflows. This result is supported by the study of [3]. Going by these realities, there is a strong indication that banks in West African countries of Nigeria and Ghana are not viable enough to attract foreign investment.

Domestic credit to private sector was found to have significant impact on foreign investment in Nigeria and Ghana. Whereas the variable is directly related to foreign investment in Ghana, which is supported by the reports of [36] and [37], it is inversely related in Nigeria. This means that the intermediation function of the Ghanaian banks is effective; it may not be unconnected by the recent divestment of notable foreign investors from Nigerian business environment to Ghana where they believe have favorable business condition.

The deposit rate of the banking system in Nigeria and Ghana are significantly and positively related to foreign investment inflows in both countries in line with the study of [38]. This proves that the banking systems in the two economies are well capitalized and the customers' are confident in the banking systems of the countries. In addition to this, the banks have the capacity to mobilize savings that may be useful to the deficit unit s of the economy

Lastly, the coefficient of bank lending rate in Ghana is positively and significantly related to foreign investment as this is supported by previous reports of [2]. This goes to validate that the interest rate is relaxed by the financial authorities to the advantage of foreign investors. In the case of Nigeria, the bank lending rate has not been favourable to foreign investment given that the variable is statistically insignificant and inversely related to the dependent variable. This result is not in variance with the situation in Nigeria as bank credits are almost unaffordable to the borrowers since banks' conditions are hardly met by borrowers, thus discouraging investment activities in the country.

\section{Conclusion and Recommendations}

The study was structured to establish the place of banking sector development in determining the inflow of foreign investment in Nigeria and Ghana given that the sector is an integral part of any given economy. The outcome of the study established that banking sector development is a major 
determinant of foreign investment in both countries. However, it was discovered that the sector have not attain its full potentials for foreign investors to take full advantage of. Foreign investment decision will to a large extent depend on the level of development of the banking sector. Looking at our findings, it is evident that the intermediation function has not been strongly effective to close the surplus to deficit gap especially in Nigeria. Furthermore, the returns on investment of the banking sector have not also encouraged the foreign investment inflows in the two West African countries. The study therefore opined that Nigeria and Ghana have not attained their full potentials in attracting foreign investment of which banking sector underdevelopment contributed significantly.

Against these backdrops, this study therefore recommends that; robust policies should be put in place to strengthen the financial structure and capital base of the banking sectors in both countries, so as to enhance their profitability prospects in the sub-region. Bank lending rate should be relaxed to an affordable extent, requirements and conditions for loan facility reviewed to improve the intermediation function of banks which is prominent in their line of duties. Authorities, operators, regulators and players in the banking sector should put in place a special interest rate for foreign investor as a measure of encouragement.

\section{References}

[1] O. Nwankwo, G.A. Olukotun, K. Olorunfemi, Effects of Globalization on Foreign Direct Investment in Nigeria, Lorem Journal of Business and Economics. 1 (2013) 11-18.

[2] A. Faroh, H. Shen, Impact of Interest Rates on Foreign Direct Investment: Case Study Sierra Leone Economy, International Journal of Business Management and Economic Research. 6 (2015) 124-132.

[3] A.C. Onuorah et al., Impact of Selected Economic Indicators on Foreign Investment Inflow in Nigeria and South Africa: Optimal Indicators Search, International Journal of Management Science and Business Administration. 1 (2015) 39-47.

[4] Chung and Lin, Portfolio Selection in Stochastic Environment Manuscript, Rady School of Business, University of California at San Diego, 2004.

[5] E. Harsch, South Africa: White Rule, Black Revolt. New York: Monad, 2014.

[6] P.I. Osiegbu, A.C. Onuorah, Fundamental of Finance, C.M. Global Co. Ltd. Asaba, Delta State, 2011.

[7] Investopedia, Available: http://www.investopedia.com/.

[8] World Bank, Available: http://data.worldbank.org/.

[9] D. Soumyananda, Factors Determining FDI to Nigeria: An Empirical Investigation, MPRA Paper, 28097 (2008).

[10] G.D.A. Macdougall, The Benefits and Costs of Private Foreign Investment Abroad: A Theoretical Approach, Economic Record, XXXVI, 1958, pp. 13-35.

[11] M.C. Kemp, The Theory of International Trade, Prentice-Hall, Ithaca, 1964, pp. 13-14.

[12] T. Itagaki, The Theory of the Multinational Firm under Exchange Rate Uncertainty, Canadian Journal of Economics. 14(1981) 276-297.

[13] D.O. Cushman, Real Exchange Rate Risk, Expectations, and the Level of Direct Investment, Review of Economics and Statistics. 67(1985) 297-308.

[14] P.J. Buckley, M. Casson, The Future of the Multinational Enterprise, Macmillan Press, London, 1976.

[15] J.F. Hennart, A Theory of Multinational Enterprise, University of Michigan, 1982.

[16] M. Casson, The Theory of Foreign Direct Investment, In: P. Buckley, (eds.), International Investment. Edward Elgar Publishing Ltd., Aldershot, England, Ltd. 1983, pp. 244-73

[17] R. Coase, The Narure of Firm, Economica, Blackwell Publishing. 4 (1937) 386-405.

[18] S.H. Hymer, The Internattional Operations of National Firms: A Study of Direct Investment, Cambridge MIT Press, 1976.

[19] L. Eden, S.R. Miller, Distances Matters: Liability of Foreignness, Institutional Distances and Ownership Strategy, Advances in international Management. 1 (2004) 187-221. 
[20] N. Hood, S. Young, The Economics of Multinational Enterprises, Longman, London, 1979, pp. 44-86.

[21] J.F Dunning, The Globalisation of Business, Routledge, London, 1973.

[22] J.F. Dunning, Towards and Ecletic Theory of International Production, 1980.

[23] H.M. Markowitz, Portfolio Selection, Journal of Finance. 7 (1979) 77-91.

[24] J.A. Schumpeter, The Theory of Economic Development, Harvard University Press, Cambridge MA, 1934.

[25] M.O. Ojo, Foreign Direct Investment and Financial Sector Growth, Asian Economic and Financial Review. 2 (2012) 262-275.

[26] N. Bayraktar, Y. Wang, Banking Sector Openness and Economic Growth, World Bank Policy Research Working Paper Series 4019, 2006.

[27] E. Berglof, G. Roland, Bank Restructuring and Soft Budget Constraints in Financial Transition, Centre for Economic Policy Research, London, Discussion Paper 125, 195).

[28] K. Tuuli, Do Efficient Banking Sectors accelerate Economic Growth in Transition Countries, BOFIT Discussion Paper, 14 (2002).

[29] E.D. Balogun, Banking Reforms and the Nigeria Economy Performance: Pitfalls and Future Policy Options, MPRA Paper 3804 (2007).

[30] P.C. Chang, C. Jia, Z. Wang, Bank Fund Reallocation and Economic Growth: Evidence from China, Journal of Banking and Finance. 34 (2010) 2753-2766.

[31] O.O. Emmanuel, E. Adegboyega, Banks and Economic Growth in Nigeria: A ReExamination of the Financial Repression Hypothesis, American Journal of Business and Management. 3 (2014) 1-9.

[32] S. Ogege, A.A. Shiro, Does Depositing Money in Bank Impact Economic Growth? Evidence from Nigeria, African Journal of Business Management. 7 (2012) 196-205.

[33] C.W.I. Granger, P. Newbold, Spurious Regressions in Econometrics, Journal of Econometrica. 2 (1977) 111-120.

[34] S. Johansen, Estimation and Hypothesis Testing of Co-integration Vectors in Gaussian Vector Autoregressive Models, Econometrica. 59 (1991) 1551-1580.

[35] S. Johansen, K. Juselius, K. Maximum Likelihood Estimation and Inference On cointegration with application to demand for money, Oxford Bulletin of Economics and Statistics. 52 (1990) 169-210.

[36] C.C. Osuji, E.E. Chigbu, An Evaluation of Financial Development and Economic Growth of Nigeria: A Causality Test, Kuwait Chapter of Arabian Journal of Business and Management Review. 1 (2012) 27-44.

[37] G.S. Balago, Financial Sector Development and Economic Growth in Nigeria: An Empirical Investigation, International Journal of Finance and Accounting. 3 (2014) 253- 265.

[38] S.Q. Ziorkiui, The Impact of Financial Sector Reform on Bank Efficiency and Financial Deepening for Savings Mobilisation in Ghana, African Economic Policy Discussion Paper 81, 2001. 